\title{
On the role of monoterpene chemistry in the remote continental boundary layer
}

\author{
E. C. Browne ${ }^{1, *}$, P. J. Wooldridge ${ }^{1}$, K.-E. Min ${ }^{2, * *}$, and R. C. Cohen ${ }^{1,2}$ \\ ${ }^{1}$ Department of Chemistry, University of California Berkeley, Berkeley, California, USA \\ ${ }^{2}$ Department of Earth and Planetary Sciences, University of California Berkeley, Berkeley, California, USA \\ *now at: Department of Civil and Environmental Engineering, Massachusetts Institute of Technology, Cambridge, \\ Massachusetts, USA \\ *** now at: NOAA Earth System Research Laboratory and Cooperative Institute for Research in Environmental Sciences, \\ University of Colorado, Boulder, Colorado, USA
}

Correspondence to: R. C. Cohen (rccohen@ berkeley.edu)

Received: 18 July 2013 - Published in Atmos. Chem. Phys. Discuss.: 27 August 2013

Revised: 20 December 2013 - Accepted: 23 December 2013 - Published: 3 February 2014

\begin{abstract}
The formation of organic nitrates $\left(\mathrm{RONO}_{2}\right)$ represents an important $\mathrm{NO}_{\mathrm{x}}\left(\mathrm{NO}_{\mathrm{x}}=\mathrm{NO}+\mathrm{NO}_{2}\right)$ sink in the remote and rural continental atmosphere, thus impacting ozone production and secondary organic aerosol (SOA) formation. In these remote and rural environments, the organic nitrates are primarily derived from biogenic volatile organic compounds (BVOCs) such as isoprene and monoterpenes. Although there are numerous studies investigating the formation of SOA from monoterpenes, there are few studies investigating monoterpene gas-phase chemistry. Using a regional chemical transport model with an extended representation of organic nitrate chemistry, we investigate the processes controlling the production and fate of monoterpene nitrates (MTNs) over the boreal forest of Canada. MTNs account for $5-12 \%$ of total oxidized nitrogen over the boreal forest, and production via $\mathrm{NO}_{3}$ chemistry is more important than production via $\mathrm{OH}$ when the $\mathrm{NO}_{\mathrm{x}}$ mixing ratio is greater than 75 pptv. The regional responses are investigated for two oxidation pathways of MTNs: one that returns $\mathrm{NO}_{\mathrm{x}}$ to the atmosphere and one that converts MTNs into a nitrate that behaves like $\mathrm{HNO}_{3}$. The likely situation is in between, and these two assumptions bracket the uncertainty about this chemistry. In the case where the MTNs return $\mathrm{NO}_{\mathrm{x}}$ after oxidation, their formation represents a net chemical $\mathrm{NO}_{\mathrm{x}}$ loss that exceeds the net loss to peroxy nitrate formation. When oxidation of MTNs produces a molecule that behaves like $\mathrm{HNO}_{3}, \mathrm{HNO}_{3}$ and MTNs are nearly equal chemical sinks for $\mathrm{NO}_{\mathrm{x}}$. This uncertainty in the oxidative fate of MTNs results in changes
\end{abstract}

in $\mathrm{NO}_{\mathrm{x}}$ of $8-14 \%$, in $\mathrm{O}_{3}$ of up to $3 \%$, and in $\mathrm{OH}$ of $3-6 \%$ between the two model simulations.

\section{Introduction}

Measurements of concentrations and fluxes indicate that monoterpenes are emitted into the atmosphere at rates large enough to affect $\mathrm{OH}$ concentrations and to contribute a large fraction of the secondary organic aerosol (SOA) mass in such diverse environments as the Amazon (e.g., Karl et al., 2007), the Mediterranean (e.g., Owen et al., 1997; Davison et al., 2009; Seco et al., 2011), pine forests of western North America (e.g., Bouvier-Brown et al., 2009; Kim et al., 2010), the boreal forest (e.g., Spirig et al., 2004; Räisänen et al., 2009; Hakola et al., 2012), and in urban regions of California's Central Valley (Rollins et al., 2012). While there is a growing body of laboratory and field measurements related to monoterpene SOA (e.g., Tunved et al., 2006; Williams et al., 2007; Fry et al., 2009, 2011; Hallquist et al., 2009; Rollins et al., 2009; Slowik et al., 2010), the gas-phase chemistry of monoterpenes that must precede SOA formation has not been explored in detail with chemical transport models (CTMs). In part this situation is due to the uncertainties in isoprene chemistry that, until recently, were so large that they overwhelmed any uncertainties in modeling monoterpene chemistry. With substantial progress in understanding isoprene oxidation sequences (e.g., Paulot et al., 2009a, b; Peeters and 
Müller, 2010), it is timely to explore the role of the gas-phase chemistry of monoterpenes in CTMs.

In the remote continental boundary layer, total $\mathrm{RONO}_{2}$ ( $\Sigma$ ANs) formation is the primary reaction determining the lifetime of $\mathrm{NO}_{\mathrm{x}}$ (Browne and Cohen, 2012; Browne et al., 2013). Thus, in regions where monoterpene emissions are important to the total $\mathrm{OH}$ and $\mathrm{NO}_{3}$ reactivity, the formation of monoterpene nitrates (MTNs) can be expected to affect the $\mathrm{NO}_{\mathrm{x}}$ lifetime, which, in turn, will affect $\mathrm{OH}$ concentrations and the ozone production efficiency. In Browne et al. (2013) observations of volatile organic compounds (VOCs), OH, and $\mathrm{NO}_{\mathrm{x}}$ were used to calculate that the instantaneous production of $\Sigma$ ANs is more rapid than production of $\mathrm{HNO}_{3}$ over the Canadian boreal forest and that a significant fraction of the $\Sigma$ ANs production rate is due to the oxidative chemistry of $\alpha$ - and $\beta$-pinene. These are the two most abundant monoterpenes on the global scale, and thus insights from the Canadian forests are likely relevant to other locations. The analysis of observations described in Browne et al. (2013) also indicates that the lifetime of $\Sigma$ ANs is shorter than that of $\mathrm{HNO}_{3}$ over the boreal forest, and that this short lifetime is due to a combination of oxidation of $\Sigma$ ANs resulting in the return of $\mathrm{NO}_{\mathrm{x}}$ to the atmosphere $\left(\mathrm{NO}_{\mathrm{x}}\right.$ recycling), deposition, and the hydrolysis of particulate $\Sigma$ ANs (forming $\mathrm{HNO}_{3}$ ). Each of these loss processes has different implications for the $\mathrm{NO}_{\mathrm{x}}$ budget: the first one recycles $\mathrm{NO}_{\mathrm{x}}$, converting a reservoir species back to the active radical pool, while the latter two result in rapid removal of odd nitrogen from the atmosphere.

This paper explores the consequences of MTN chemistry for nitrogen oxides as well as the drivers of atmospheric oxidative chemistry (e.g., $\mathrm{OH}, \mathrm{O}_{3}$ ) using the Weather Research and Forecasting model with Chemistry (WRF-Chem) (Grell et al., 2005), a regional chemical transport model. The model is run using an extended representation of organic nitrate chemistry and the model calculations are compared to observations from the NASA Arctic Research of the Composition of the Troposphere from Aircraft and Satellites (ARCTAS) campaign (Jacob et al., 2010) over the Canadian boreal forest. We then explore the relative contributions of $\mathrm{OH}$ and $\mathrm{NO}_{3}$ chemistry to the production of MTNs and investigate how the total production impacts $\mathrm{NO}_{\mathrm{y}}$ partitioning. To understand the range of possible roles for MTNs, we examine their sinks, comparing model predictions for several atmospheric constituents in scenarios where oxidation of MTNs results in the release of $\mathrm{NO}_{\mathrm{x}}$ to predictions where the $-\mathrm{ONO}_{2}$ functional group is retained as an organic nitrate.

\section{Model description}

\subsection{Domain and emissions}

WRF-Chem v3.2.1 (Grell et al., 2005) at $36 \mathrm{~km} \times 36 \mathrm{~km}$ resolution over a $5364 \mathrm{~km}$ (east-west) by $3384 \mathrm{~km}$ (north- south) domain centered over Canada was used for this study. Data from the outer $180 \mathrm{~km}$ of the domain are discarded to allow for relaxation of the boundary conditions taken from MOZART-4 model (Emmons et al., 2010) using meteorology from GEOS-5 (available at http://www.acd.ucar.edu/ wrf-chem/). Meteorological data are from the North American Regional Reanalysis and the model was run for six days as a spin-up prior to simulating the time period corresponding to the ARCTAS measurements over the Canadian boreal forest from 29 June to 13 July 2008. The goal was not to directly simulate the ARCTAS conditions but rather to investigate the impacts of MTNs on $\mathrm{NO}_{\mathrm{x}}$ and $\mathrm{O}_{3}$ in the boreal forest. To that end, fire emissions of $\mathrm{NO}_{\mathrm{x}}$ and volatile organic compounds were not included in the model. Modeled anthropogenic emissions were from Reanalysis of Tropospheric composition (RETRO) and Emissions Database for Global Atmospheric Research (EDGAR) using the global emissions preprocessor for WRF-Chem (Freitas et al., 2011) and modeled biogenic emissions were from the Model of Emissions of Gases and Aerosols from Nature (MEGAN) (Guenther et al., 2006) available at http://www.acd.ucar.edu/wrf-chem/. In order to achieve approximate agreement with the ARCTAS observations of $\mathrm{NO}_{\mathrm{x}}$ and biogenic volatile organic compounds (BVOCs), isoprene emissions were uniformly reduced by $20 \%$ and soil $\mathrm{NO}_{\mathrm{x}}$, lumped $\alpha$-pinene, and lumped limonene emissions were each increased by a factor of two.

Aerosols are treated using the Modal Aerosol Dynamics Model for Europe (MADE) with the Secondary Organic Aerosol Model (SORGAM) (Ackermann et al., 1998; Schell et al., 2001). This mechanism is a "two-product model" approach to aerosols and consequently does not treat the partitioning of individual chemical species such as organic nitrates. Therefore, particle-phase partitioning does not impact the distribution of organic nitrates.

Although more detailed aerosol chemical mechanisms that track the individual species as they transfer between the gas and particle phases do exist (e.g., Derwent et al., 2003; Bonn et al., 2005), our focus here is on investigating the impacts of the gas-phase representation of the chemistry; a full consideration of the aerosol is beyond the scope of this work.

\subsection{Chemical mechanism}

The chemical mechanism is based on the RACM2 mechanism (Goliff et al., 2013), which in its original form includes three organic nitrate species: two isoprene-derived nitrates and one lumped nitrate (ONIT). This lumped nitrate is long-lived $(>100 \mathrm{~h}$ lifetime to oxidation by $1 \times 10^{6}$ molecules $\mathrm{cm}^{-3}$ of $\mathrm{OH}$ at $298 \mathrm{~K}$ ), assumed to release $\mathrm{NO}_{2}$ with $100 \%$ efficiency upon oxidation, and has a long lifetime to deposition (Henry's law constant of $\sim 1 \mathrm{M} \mathrm{atm}^{-1}$ ). In contrast, Henry's law coefficients for hydroxy nitrates have been measured to be on the order of $10^{3}-10^{5} \mathrm{M} \mathrm{atm}^{-1}$ (Shepson et al., 1996; Treves et al., 2000). Monoterpene nitrates are likely to be multifunctional nitrates 
(containing a nitrate and most likely a hydroxy or peroxide group) and are thus likely to have deposition rates that are much faster than the rate assumed for ONIT. As a 10-carbon molecule, monoterpene nitrates will have a faster oxidation rate and return $\mathrm{NO}_{2}$ to the atmosphere with less than $100 \%$ efficiency. Furthermore, some monoterpene nitrates will be unsaturated molecules that in addition to having a faster $\mathrm{OH}$ oxidation rate will also undergo ozonolysis.

Due to these issues, investigating the low- $\mathrm{NO}_{\mathrm{x}}$, highBVOC chemistry of organic nitrates required an expansion of the organic nitrate chemistry. The changes we make to the RACM2 mechanism include the reclassification of the lumped nitrates into the new species and the addition of oxidation and photolysis reactions for the new organic nitrate species. The RACM2 mechanism includes two lumped species to represent low-reactivity (lumped into the model species $\alpha$-pinene) and high-reactivity (lumped as limonene) monoterpenes. Most of the monoterpene oxidation products (e.g., pinonaldehyde, organic nitrates) are lumped into generic products (e.g., aldehydes and ketones, ONIT).

During the day, monoterpene nitrates are formed from the minor channel of the reaction of the monoterpene peroxy radical with NO:

$$
\mathrm{MTO}_{2}+\mathrm{NO} \rightarrow \mathrm{MTO}+\mathrm{NO}_{2} \quad(1-\alpha),
$$

$$
\mathrm{MTO}_{2}+\mathrm{NO} \rightarrow \mathrm{MTN}(\alpha),
$$

where $\mathrm{MTO}_{2}$ is the monoterpene-derived peroxy radical formed from the reaction of monoterpenes with $\mathrm{OH}, \mathrm{MTO}$ is the monoterpene-derived alkoxy radical, and $\alpha$ is the yield of MTNs. At night, the reaction of $\mathrm{NO}_{3}$ with monoterpenes results in the formation of a nitrooxy peroxy radical $\left(\mathrm{MTNO}_{2}\right)$ :

$\mathrm{MT}+\mathrm{NO}_{3} \rightarrow \mathrm{MTNO}_{2}$

This radical reacts with $\mathrm{NO}, \mathrm{NO}_{3}, \mathrm{HO}_{2}$, or $\mathrm{RO}_{2}$ with the following possible channels:

$$
\begin{aligned}
\mathrm{MTNO}_{2} & +\mathrm{NO} / \mathrm{NO}_{3} / \mathrm{HO}_{2} / \mathrm{RO}_{2} \rightarrow \mathrm{NO}_{2} \\
& + \text { products }(1-\beta),
\end{aligned}
$$

$$
\mathrm{MTNO}_{2}+\mathrm{NO} / \mathrm{NO}_{3} / \mathrm{HO}_{2} / \mathrm{RO}_{2} \rightarrow \mathrm{MTN}(\beta),
$$

where $\beta$ represents the yield of MTNs from this nocturnal chemistry. The exact reactions for both monoterpene species used in RACM2 and the identity of the products can be found in the supplemental material and are discussed briefly below.

For daytime chemistry, RACM2 has an $18 \%$ yield of organic nitrate from the reaction of the lumped $\alpha$-pinene peroxy radical with $\mathrm{NO}$ and a $0 \%$ yield for the reaction of the lumped limonene peroxy radical with NO. In our update, the yield from limonene was increased to $22 \%$ as reported in Leungsakul et al. (2005) and as is assumed in the Master Chemical Mechanism v3.2 (MCM v3.2) available at http://mcm.leeds.ac.uk/MCM (Jenkin et al., 1997; Saunders et al., 2003); the yields of the other monoterpene oxidation products are reduced to account for the increase in organic nitrate yield. The exact yield of monoterpene nitrates carries some uncertainty since yields have only been directly measured for a few specific monoterpenes and these measurements are subject to biases due to loss of the nitrates to aerosol, chamber walls, and/or hydrolysis. The exact yield may be lower or higher than used here; however, any reasonable changes will only impact the exact numerical results and not the overall conclusion that MTNs are important in the $\mathrm{NO}_{\mathrm{x}}$ and $\mathrm{NO}_{\mathrm{y}}$ budgets.

RACM2 assumes that the oxidation of monoterpenes by $\mathrm{NO}_{3}$ results in the formation of two nitrooxy peroxy radicals: one that primarily recycles $\mathrm{NO}_{\mathrm{x}}$, and one that primarily forms a nitrate. The split between these two radicals that is in RACM2 is used here, but they are renamed such that their products form MTNs (70\% saturated and $30 \%$ unsaturated). The split of peroxy radicals for the lumped limonene is based on Spittler et al. (2006), who report an organic nitrate yield of $67 \%$. Fry et al. (2011) recently reported a smaller organic nitrate yield $(30 \%)$ from the reaction of $\mathrm{NO}_{3}$ with limonene. The reason for the discrepancies between the two studies is unclear.

Two monoterpene-derived nitrates are introduced, one unsaturated (UTONIT) and one saturated (TONIT). The lumped limonene peroxy radicals react with NO to form unsaturated nitrates, while lumped $\alpha$-pinene peroxy radicals react with NO to yield both saturated and unsaturated nitrates with yields of 12 and $6 \%$, respectively. We note that this branching is not constrained by laboratory measurements; however changes to this branching should only be important if the $\mathrm{NO}_{\mathrm{x}}$ recycling from monoterpene nitrate oxidation is high. Oxidation rates of the MTN with $\mathrm{OH}$ are calculated using weighted averages of the MCM v3.2 rates of $\alpha$-pinene and $\beta$-pinene (assuming a 50-50 mixture and ignoring the $\mathrm{OH}$ abstraction channels) for TONIT and from limonene for UTONIT. The ozonolysis rate of UTONIT is estimated using the EPA Estimation Program Interface (EPI) Suite v4.1 (available at http://www.epa.gov/opptintr/ exposure/pubs/episuite.htm) (US EPA, 2011). In what we refer to as our BASE case, oxidation of both TONIT and UTONIT generates a second-generation monoterpene nitrate which is oxidized, photolyzed, and deposited identically to $\mathrm{HNO}_{3}$.

Assessing the impact of monoterpene chemistry on the $\mathrm{NO}_{\mathrm{x}}$ budget also requires updating the isoprene chemistry scheme to be consistent with recent laboratory and theoretical studies. Our isoprene oxidation scheme follows that of Paulot et al. (2009a, b). The formation of hydro-peroxy aldehydes (HPALD) from the isomerization reaction of isoprene 


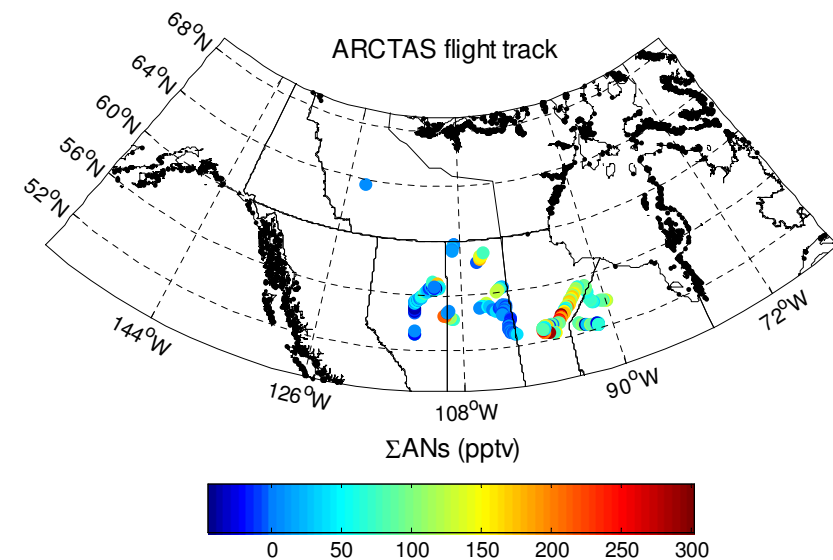

Fig. 1. Map of ARCTAS measurements of $\Sigma$ ANs used in this analysis. These locations are removed from recent biomass burning influences and are at pressures greater than $600 \mathrm{mbar}$.

peroxy radicals is included using the rate measured by Crounse et al. (2011). The fate of HPALD follows the assumptions of Peeters and Müller (2010). The isomerization of the non-acyl methacrolein peroxy radical is included using the rate and products from Crounse et al. (2012). Peroxy radical cross reactions were determined following the protocol of Madronich and Calvert (1990) updated in some cases to Tyndall et al. (2001) and using updated reaction rates from IUPAC (Atkinson et al., 2006). Reactions of peroxy radicals with $\mathrm{HO}_{2}$ were determined using the product yields from Hasson et al. (2004). Full details regarding the isoprene chemistry can be found in the Supplement.

Recently, Xie et al. (2013) implemented a revised isoprene chemistry scheme in SAPRC-07 based on assumptions similar to ours. Xie et al. (2013) show that this scheme, as implemented in the US EPA CMAQ (Community Multiscale Air Quality) model, results in significant improvement in the representation of chemistry over eastern US forests. They include a comparison of their results to the $\Sigma$ ANs measured from the aircraft (Perring et al., 2009) and find good agreement.

Although of minor importance in the remote boreal forest, the treatment of the organic nitrates that are primarily of anthropogenic origin also required extension. The extended organic nitrate chemistry includes four nitrates primarily of anthropogenic origin (aromatic-derived, multifunctional unsaturated, multifunctional saturated, and monofunctional saturated nitrates) that were partitioned from the lumped precursors following the procedure of Middleton et al. (1990) and using branching ratios from Arey et al. (2001) and MCM v3.2. The yields of the nitrates are generally unchanged from RACM2, with the exception of the yield from the lumped species representing short-lived alkanes, alcohols, esters, and alkynes. This yield, originally derived using the branching ratio parameterization from Carter and Atkinson (1989), was reduced (and the non-nitrate products correspondingly in-
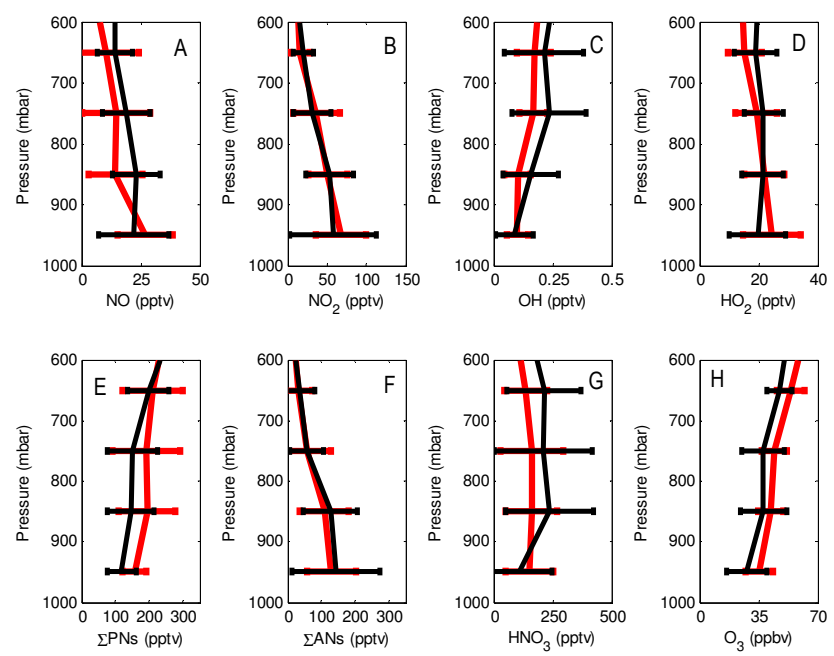

Fig. 2. Mean concentrations binned by altitude of (red) ARCTAS observations and (black) WRF-Chem sampled along the flight track for (a) $\mathrm{NO}$, (b) $\mathrm{NO}_{2}$, (c) $\mathrm{OH}$, (d) $\mathrm{HO}_{2}$, (e) $\Sigma$ PNs, (f) $\Sigma \mathrm{ANs}$, (g) $\mathrm{HNO}_{3}$, and (h) $\mathrm{O}_{3}$. ARCTAS observations are averaged to the resolution of WRF-Chem.

creased) to be consistent with the more recent parameterization from Arey et al. (2001).

The elements of our extended mechanism, including oxidation, photolysis, and dry deposition rates and reactions, are listed in the Supplement.

\section{Evaluation of the model using ARCTAS observations}

\subsection{Description of ARCTAS observations}

The model is compared to ARCTAS data from the $1 \mathrm{~min}$ merge version 13 , which is publically available at http:// www-air.larc.nasa.gov/missions/arctas/dataaccess.htm. The data used include flight numbers $17-20$ and 23-24. A full summary of the flights and the measurement suite can be found in Jacob et al. (2010). A map of the flight tracks, colored by observed $\Sigma$ ANs concentration, is shown in Fig. 1. Comparisons of the vertical profiles from the surface to 600 mbar ( $\sim 4.2 \mathrm{~km}$ pressure altitude) between the BASE model and the ARCTAS measurements for key $\mathrm{NO}_{\mathrm{y}}$ and $\mathrm{HO}_{\mathrm{x}}$ species are shown in Fig. 2. In making these comparisons, only ARCTAS data over land and removed from biomass burning influences (as defined from inspection of $\mathrm{CO}, \mathrm{HCN}$, and $\mathrm{CH}_{3} \mathrm{CN}$ concentrations) are used.

Briefly, the measurements used to compare to the model output are from the NCAR chemiluminescence instrument for $\mathrm{NO}$ and $\mathrm{O}_{3}$ (Weinheimer et al., 1994), the UC Berkeley thermal dissociation laser-induced fluorescence (TD-LIF) instrument for $\mathrm{NO}_{2}, \Sigma$ PNs, and $\Sigma$ ANs (Thornton et al., 2000; Day et al., 2002; Wooldridge et al., 2010), the Pennsylvania State University LIF for $\mathrm{OH}$ and $\mathrm{HO}_{2}$ (Faloona et al., 
2004), and the California Institute of Technology chemical ionization mass spectrometer for $\mathrm{HNO}_{3}$ (Crounse et al., 2006). Biogenic species include $\alpha$ - and $\beta$-pinene from the UC Irvine whole-air samples (Simpson et al., 2011) and isoprene, methyl vinyl ketone (MVK), and methacrolein (MACR) from the trace organic gas analyzer (Apel et al., 2003).

The ARCTAS measurements are averaged horizontally to the WRF-Chem resolution, use the closest WRF-Chem output time (output is hourly), and sample the WRF-Chem model along the flight track. However, during one flight leg (flight \#20 at 21:51 to 22:28 UTC) the aircraft sampled a plume high in biogenics that WRF-Chem predicts to be southeast of the aircraft. We use the WRF-Chem predictions from this plume and not the flight location in our comparison.

\subsection{Comparison of modeled and measured concentrations}

The measurements and model results are averaged into 100 mbar bins to evaluate the ability of the model to capture the regional chemistry, as shown in Figs. 2 and 3. Overall the model compares favorably to the measurements of the different components of $\mathrm{NO}_{\mathrm{y}}$ as well as $\mathrm{OH}, \mathrm{HO}_{2}$, and $\mathrm{O}_{3}$, with the mean modeled value always within one standard deviation of the measured mean. $\mathrm{NO}, \mathrm{OH}$, and $\mathrm{HNO}_{3}$ are, however, consistently higher in the model than in the measurements, with the mean in each bin higher than the measurement by an average of 3 pptv (27\%), 0.04 pptv (27\%), and 40 pptv (27\%), respectively. The mean values of the modeled total peroxy nitrates ( $\Sigma$ PNs) and $\mathrm{O}_{3}$ are lower than the measurements by 35 pptv (19\%) and 6 ppbv (14\%), respectively. Some of the discrepancies are due to differences between modeled and observed clouds as reflected in comparison of measured and modeled photolysis rates of $\mathrm{NO}_{2}$ that are $30 \%$ higher on average in WRF (not shown). Overall, it can be concluded that within error, the model captures the regional features $\mathrm{NO}_{\mathrm{y}}$, $\mathrm{HO}_{\mathrm{x}}$, and $\mathrm{O}_{3}$ despite some biases in the means of individual species.

Figure 3 shows the measurement-model comparison for the major biogenic species. As stated in Sect. 2.1, emissions over the entire domain have been reduced by $20 \%$ for isoprene and have been doubled for monoterpenes to more closely match the ARCTAS observations. Due to errors in the WRF-Chem representation of the wind field, there are still discrepancies between the measurement and model. In the 950 mbar bin the mean value of the model and measurements agree to within 4 pptv (3\%); however, since only $\alpha$ and $\beta$-pinene are measured during ARCTAS, this number is likely lower than the actual total monoterpene concentration. For instance the emissions of camphene and 3-carene were larger than those of $\alpha$-pinene as measured by enclosure measurements of black spruce trees (Fulton et al., 1998). Black spruce trees are prevalent in the Canadian boreal forest. Summertime measurements in the Finnish boreal forest
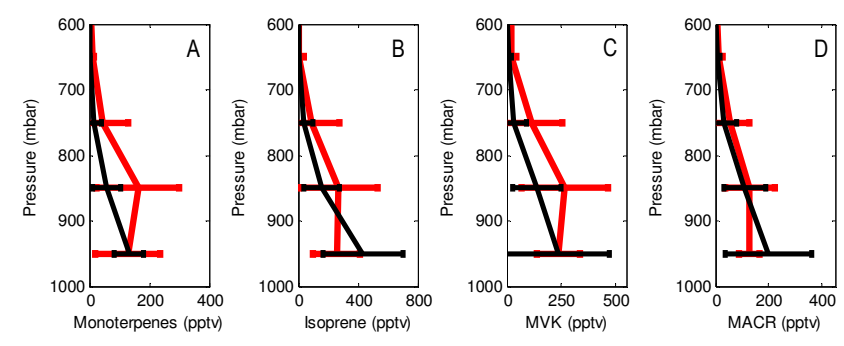

Fig. 3. Same as Fig. 2 but for (a) monoterpenes (only $\alpha$ - and $\beta$ pinene were measured during ARCTAS), (b) isoprene, (c) methyl vinyl ketone, and (d) methacrolein. The apparent maximum in the ARCTAS profiles (red) at $800-900$ mbar is due to the plume high in biogenics sampled during flight \#20 at 21:51 to 22:28 UTC. If this plume is removed, both the model and the measurements show a smoothly decreasing profile with increasing altitude, as expected for reactive species with surface emissions.

indicate that $\alpha$ - and $\beta$-pinene account for just over $60 \%$ of the monoterpene concentration (Hakola et al., 2012).

There is more isoprene, $177 \mathrm{pptv}(69 \%)$, in the model than in the measurements at the lowest altitude, but at higher altitudes the model has less isoprene than was measured (by 113 pptv $-42 \%$ at 850 mbar (Fig. 3b)). At 950 mbar the ratio of methacrolein (MACR) to isoprene is similar in the model (0.46) and the measurements (0.50), but the ratio of methyl vinyl ketone (MVK) to isoprene is much different ( 0.54 in the model compared to 0.93 ). This suggests the branching of MVK and MACR in either the $\mathrm{OH}$ oxidation or ozonolysis of isoprene in this low- $\mathrm{NO}_{\mathrm{x}}$ environment is not described properly in the chemical mechanism (e.g., Liu et al., 2013), that there are some transport issues affecting the photochemical age of the air masses, or that depositional processes are poorly represented.

Figure $4 \mathrm{a}$ and $\mathrm{b}$ show comparisons of the WRF-Chem $\Sigma$ ANs production to the calculation of $\Sigma$ AN production from the VOCs measured during ARCTAS (Browne et al., 2013). The two different calculations both show that biogenic precursors (isoprene, MVK, MACR, and monoterpenes) account for the vast majority of $\Sigma$ AN production. In WRFChem, monoterpenes account for only $16 \%$ of the total production, compared to $30 \%$ during ARCTAS. This is consistent with the lower concentration of monoterpenes in the model (Fig. 3a).

The composition of $\Sigma$ ANs as calculated by WRF-Chem is shown in Fig. 5a along with the ARCTAS observations of the contribution of small $(\leq \mathrm{C} 5)$ alkyl nitrates measured in the whole-air samples (Simpson et al., 2011) to the total $\Sigma$ ANs measured by thermal dissociation laser-induced fluorescence (full details regarding this measurement during ARCTAS can be found in Browne et al., 2013). During ARCTAS the small alkyl nitrates measured in whole-air samples accounted for $26 \%$ (median - Fig. 5 b) of the $\Sigma$ ANs measurement, which is higher than the WRF-Chem prediction of $19 \%$. These small differences in the long-lived nitrates are 


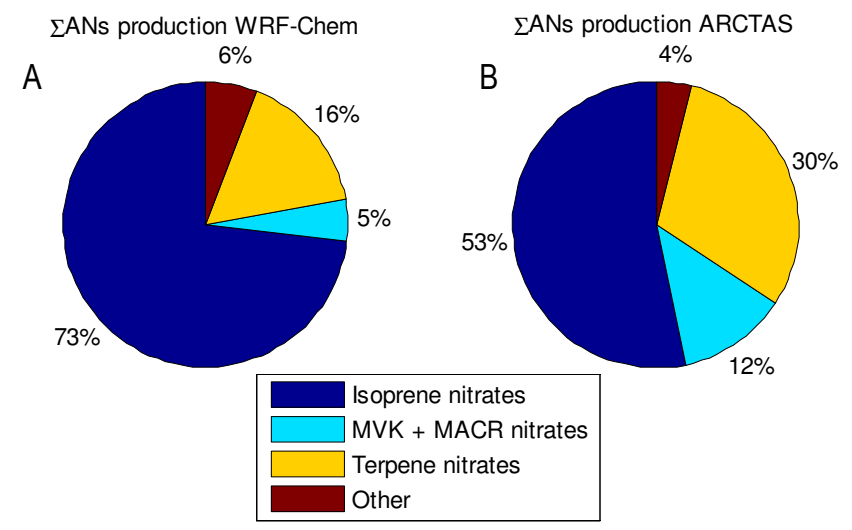

Fig. 4. (a) Instantaneous $\Sigma$ ANs production rate as calculated by WRF-Chem along the ARCTAS flight track at altitudes less than $2 \mathrm{~km}$. (b) The calculated instantaneous $\Sigma$ ANs production based on the volatile organic compound precursors measured during ARCTAS for altitudes less than $2 \mathrm{~km}$. Details regarding this calculation can be found in Browne et al. (2013).

likely associated with the boundary conditions. Due to their long lifetime, they do not affect any of the conclusions about the monoterpene chemistry.

In general, after adjustment of the emissions, the modeled and measured vertically averaged profiles of select BVOCs, $\mathrm{NO}_{\mathrm{y}}$ constituents, $\mathrm{HO}_{\mathrm{x}}$, and $\mathrm{O}_{3}$ agree to within one standard deviation over the domain (the boreal forest of Canada), and thus it can be concluded that the chemistry is represented well. There do exist some biases in the modeled mean values; however, the results presented below are fairly insensitive to these biases since two model runs are being compared to each other.

\section{Monoterpene nitrate abundance, formation, and fate}

The role of MTNs can be assessed using a $24 \mathrm{~h}$ boundary layer average from the 15 days corresponding to the ARCTAS measurements (28 June-13 July 2008) and using model output from areas located north of $49^{\circ} \mathrm{N}$ and defined as forest or wooded tundra in the USGS land use categories, an area of $5.59 \times 10^{6} \mathrm{~km}^{2} . \mathrm{NO}_{\mathrm{x}}$ is defined as $\mathrm{NO}+\mathrm{NO}_{2}+\mathrm{NO}_{3}+2 \times \mathrm{N}_{2} \mathrm{O}_{5}$. In addition to assuming that the oxidation of MTNs forms a nitrate that behaves identically to $\mathrm{HNO}_{3}$ as in the BASE case, it is instructive to compare a simulation in which monoterpene-derived nitrates release $\mathrm{NO}_{2}$ upon oxidation (referred to as RECYCLE). These two situations represent extremes, and the likely situation is between them. Since there are no experimental constraints on the $\mathrm{NO}_{\mathrm{x}}$ recycling from MTNs, the differences between the RECYCLE and BASE cases are useful in defining a range for the effects of MTNs.
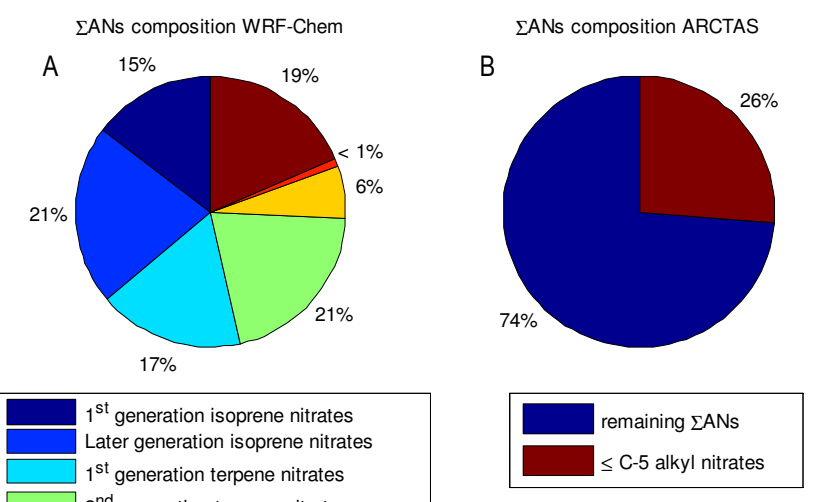

$1^{\text {st }}$ generation isoprene nitrates Later generation isoprene nitrates

$1^{\text {st }}$ generation terpene nitrates

$2^{\text {nd }}$ generation terpene nitrates

MVK nitrates

MACR nitrates

Other

Fig. 5. (a) The $\Sigma$ ANs composition predicted by WRF-Chem along the flight track at altitudes less than $2 \mathrm{~km}$. (b) The $\Sigma$ ANs composition during ARCTAS for the same altitudes. The $\leq \mathrm{C} 5$ nitrates were measured in the whole-air samples and the total was measured using TD-LIF. Details are in Browne et al. (2013).

\subsection{Abundance}

In the BASE case, over most of the boreal forest, firstgeneration MTNs account for $\sim 20 \%$ of $\Sigma$ ANs and secondgeneration MTNs account for $\sim 10-15 \%$ (not shown). Together, the MTNs account for $30-40 \%$ of $\Sigma$ ANs over most of the domain and 60-80\% over British Columbia (not shown). However, although the fractional contributions over British Columbia are large, the absolute concentrations are very small in this region (Fig. 6a). The remaining $\Sigma$ ANs are primarily of biogenic origin. In the northern part of the domain (north of approximately $56^{\circ} \mathrm{N}$ ) $\sim 90-95 \%$ of $\Sigma \mathrm{AN}$ are biogenic. This number decreases to $\sim 80-85 \%$ in the southern portion (which has better overlap with the ARCTAS flight data), due to more anthropogenic influence (not shown).

Monoterpene nitrates are a significant contribution to $\mathrm{NO}_{\mathrm{y}}$, accounting for $\sim 8-12 \%$ of $\mathrm{NO}_{\mathrm{y}}$ over most of the domain (Fig. 6b); however in general they contribute less to $\mathrm{NO}_{\mathrm{y}}(\sim 6-8 \%)$ in areas where the absolute concentration of $\mathrm{NO}_{\mathrm{y}}$ is highest (Fig. 6a). These high concentrations are in southern Canada, where the anthropogenic influence on total $\mathrm{NO}_{\mathrm{y}}$ is larger. In the RECYCLE case the contribution of MTNs to $\mathrm{NO}_{\mathrm{y}}$ has the same spatial distribution; however, the contribution to $\mathrm{NO}_{\mathrm{y}}$ is reduced to $\sim 4-8.5 \%$ over most of the domain.

\subsection{Formation}

Monoterpene nitrates may be formed as a result of either $\mathrm{OH}$ or $\mathrm{NO}_{3}$ oxidation. Figure 7 shows the absolute production rates as a function of $\mathrm{NO}_{\mathrm{x}}$ mixing ratio. Each point in the figure represents an equal number of model boxes (208). 

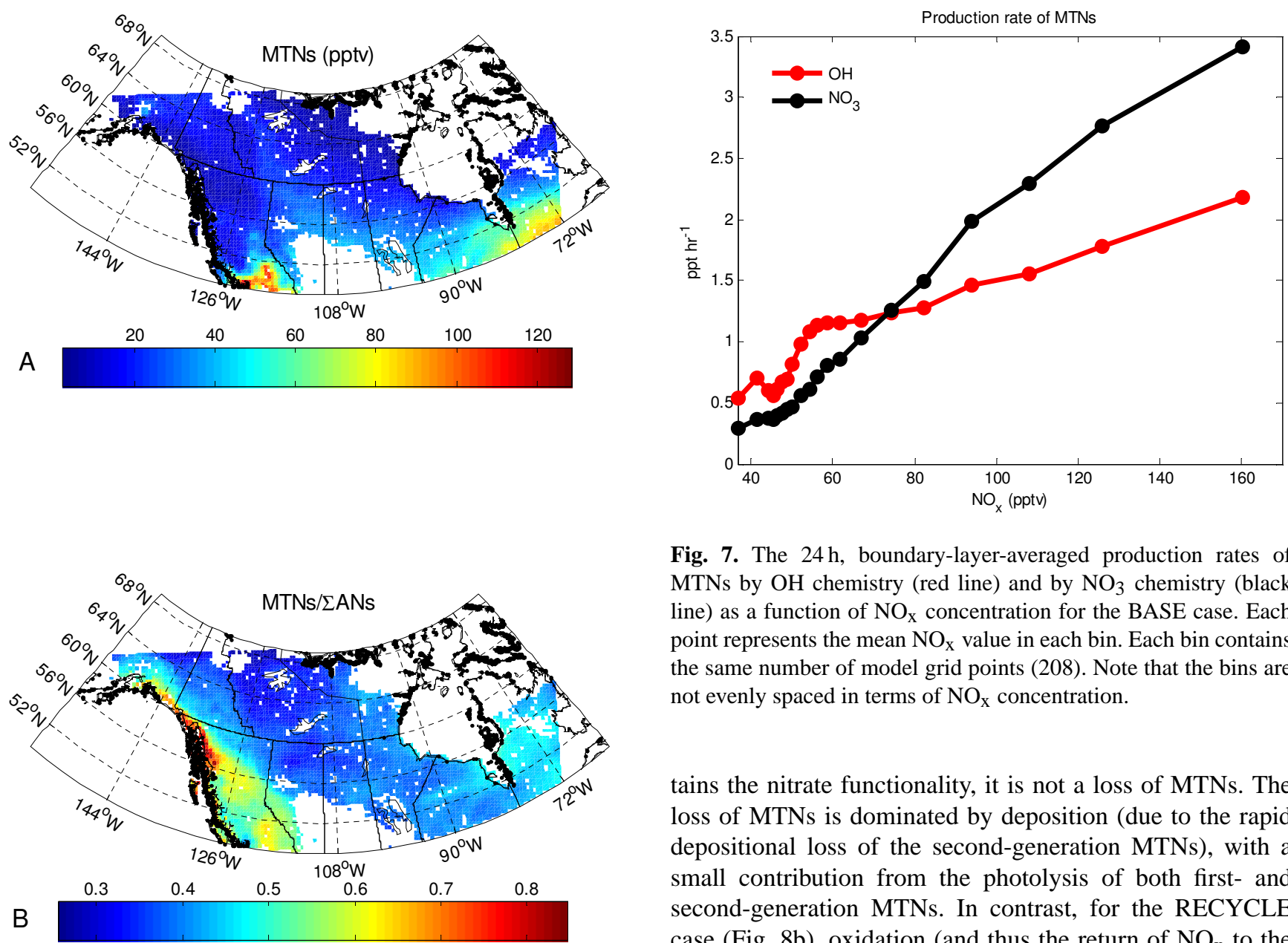

Fig. 7. The $24 \mathrm{~h}$, boundary-layer-averaged production rates of MTNs by $\mathrm{OH}$ chemistry (red line) and by $\mathrm{NO}_{3}$ chemistry (black line) as a function of $\mathrm{NO}_{\mathrm{x}}$ concentration for the BASE case. Each point represents the mean $\mathrm{NO}_{\mathrm{x}}$ value in each bin. Each bin contains the same number of model grid points (208). Note that the bins are not evenly spaced in terms of $\mathrm{NO}_{\mathrm{x}}$ concentration.

Fig. 6. (a) The $24 \mathrm{~h}$, boundary-layer-averaged absolute concentration of MTNs in the BASE case. (b) Fractional contribution of MTNs to total oxidized nitrogen in the BASE case.

Production is dominated by $\mathrm{OH}$ chemistry for $\mathrm{NO}_{\mathrm{x}}$ concentrations $<\sim 75$ pptv and is dominated by $\mathrm{NO}_{3}$ chemistry for higher concentrations of $\mathrm{NO}_{\mathrm{x}}$. Since these averages are weighted by mass, this split between $\mathrm{NO}_{3}$ and $\mathrm{OH}$ production is not an artifact due to differences in boundary layer heights between day and night. Rather the high production rates are due to a sharp increase in $\mathrm{NO}_{3}$ and in the $\mathrm{NO}_{3}$-to$\mathrm{OH}$ ratio above 50 pptv $\mathrm{NO}_{\mathrm{x}}$ (not shown). There are no significant differences between the BASE and the RECYCLE (not shown) cases in the absolute or fractional production of MTNs.

\subsection{Fate}

Figure 8a shows the fractional loss of MTNs to OH, photolysis, and deposition for the BASE case. In the BASE case it is assumed that, upon oxidation, first-generation MTNs are converted into a more highly functionalized nitrate that behaves identically to $\mathrm{HNO}_{3}$. Since this oxidation step re-

tains the nitrate functionality, it is not a loss of MTNs. The loss of MTNs is dominated by deposition (due to the rapid depositional loss of the second-generation MTNs), with a small contribution from the photolysis of both first- and second-generation MTNs. In contrast, for the RECYCLE case (Fig. 8b), oxidation (and thus the return of $\mathrm{NO}_{\mathrm{x}}$ to the atmosphere) is the primary contributor $(48 \%)$ to the loss of MTNs. Although oxidation by $\mathrm{OH}$ is more important, ozonolysis accounts for roughly one-third of the $\mathrm{NO}_{\mathrm{x}}$ loss. Because most of the deposition loss in the BASE case is due to deposition of the second-generation nitrate, which is not formed in the RECYCLE case, deposition is a smaller loss process in the RECYCLE case (Fig. 8b) than in the BASE case (Fig. 8a); however it is still important, accounting for $16 \%$ of the loss. The calculations show that the majority $(93 \%)$ of the MTN loss removes $\mathrm{NO}_{\mathrm{x}}$ from the atmosphere by deposition in the BASE case, whereas this permanent removal drops to $16 \%$ of the MTNs in the RECYCLE case.

The averaged MTNs loss rate is $8 \%$ greater in the RECYCLE case $\left(1.58 \mathrm{pptv}^{-1}\right)$ compared to the BASE case $\left(1.47 \mathrm{pptv} \mathrm{h}^{-1}\right)$; however the averaged production rate is $\sim 7 \%$ greater in the RECYCLE case as well. These differences are due to the changes in $\mathrm{OH}, \mathrm{O}_{3}$, and $\mathrm{NO}_{\mathrm{x}}$ that are discussed in the next section. As a result of the slightly higher net MTNs loss in the RECYCLE case, the total concentration of MTNs is higher in the BASE case, with the second-generation MTNs accounting for most of this difference. In fact, the concentration of the first-generation MTNs is slightly larger $(\sim 5 \%)$ in the RECYCLE case. This larger value comes from the difference between the production of 


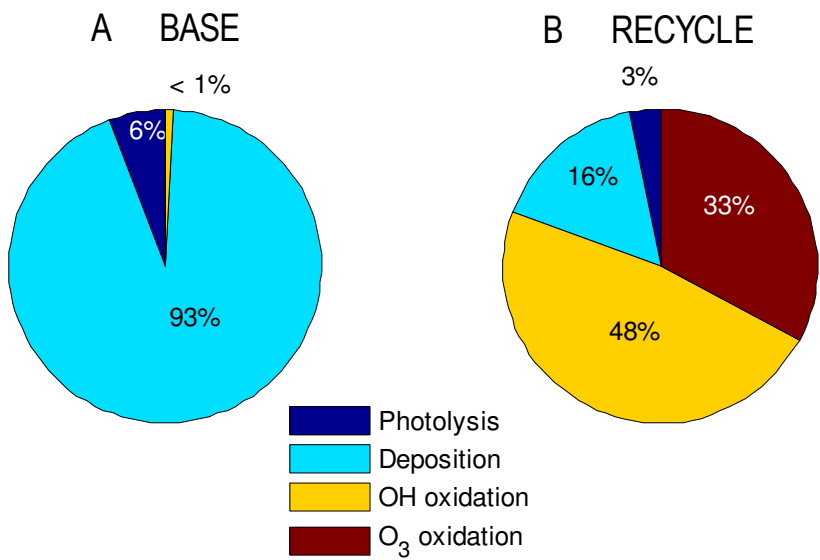

Fig. 8. The partitioning of the $24 \mathrm{~h}$, boundary-layer-averaged loss processes of MTNs in (a) the BASE case and (b) the RECYCLE case. The averaged total loss is $8 \%$ larger in the RECYCLE case compared to the BASE case. Loss of MTNs through oxidation by $\mathrm{OH}$ or $\mathrm{O}_{3}$ and by photolysis results in the return of $\mathrm{NO}_{\mathrm{x}}$ to the atmosphere. Loss of MTNs through deposition removes $\mathrm{NO}_{\mathrm{x}}$ from the atmosphere and introduces it into the biosphere.

first-generation MTNs and their loss through reaction with $\mathrm{OH}$ and that $\mathrm{O}_{3}$ is larger in the RECYCLE case.

\section{MTNs and $\mathrm{NO}_{\mathrm{x}}, \mathrm{NO}_{\mathrm{y}}, \mathrm{OH}$, and $\mathrm{O}_{3}$}

\section{$5.1 \mathrm{NO}_{\mathrm{x}}$ and $\mathrm{NO}_{\mathrm{y}}$}

The lifetime of $\mathrm{NO}_{\mathrm{x}}$ and the mechanism of $\mathrm{NO}_{\mathrm{x}}$ removal are affected by MTN chemistry, as shown in Fig. 9. The net chemical loss rates (loss of $\mathrm{NO}_{\mathrm{x}}$ - production from photolysis and oxidation) are shown as a function of $\mathrm{NO}_{\mathrm{x}}$ to illustrate how, in low- $\mathrm{NO}_{\mathrm{x}}$ environments, the formation of $\Sigma$ ANs represents the dominate $\mathrm{NO}_{\mathrm{x}}$ loss as discussed in Browne and Cohen (2012). Figure 9 also shows that the net $\mathrm{NO}_{\mathrm{x}}$ loss to MTNs (red lines) is always larger than the $\mathrm{NO}_{\mathrm{x}}$ loss to $\Sigma \mathrm{PNs}$ and in the BASE case is similar to the $\mathrm{NO}_{\mathrm{x}}$ loss to $\mathrm{HNO}_{3}$. Monoterpene nitrate formation thus represents a significant $\mathrm{NO}_{\mathrm{x}}$ sink.

The decrease in $\mathrm{NO}_{\mathrm{x}}$ loss to MTNs in the RECYCLE case compared to the BASE case is evident when the $\mathrm{NO}_{\mathrm{x}}$ concentrations of the BASE and RECYCLE cases are compared. The oxidation of MTNs in the RECYCLE case results in a $\sim 8-14 \%$ increase in $\mathrm{NO}_{\mathrm{x}}$ (mean of $\sim 5 \mathrm{pptv}$ and max of 25 pptv) (Fig. 9a). This increase in $\mathrm{NO}_{\mathrm{x}}$ results in an increase in $\Sigma$ PNs by almost the same amount (mean $8.5 \mathrm{pptv}$ and max of $30 \mathrm{pptv}$ ) with the same spatial distribution (not shown) in the RECYCLE versus the BASE case.

\section{$5.2 \mathrm{OH}$ and $\mathrm{O}_{3}$}

The $\mathrm{NO}_{\mathrm{x}}$ differences between the BASE and RECYCLE cases in turn affect the concentrations of $\mathrm{O}_{3}$ and $\mathrm{OH}$.

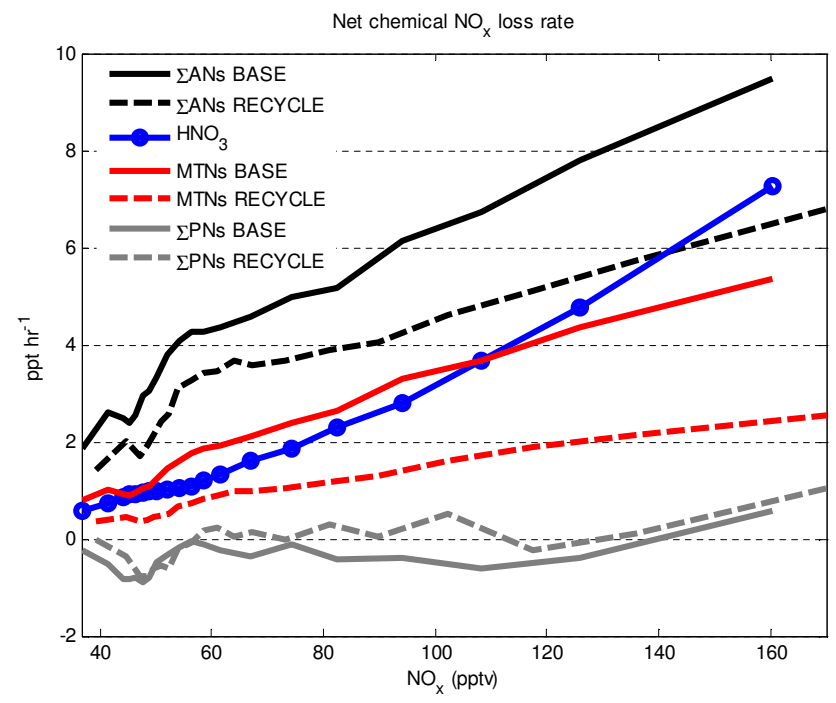

Fig. 9. The $24 \mathrm{~h}$, boundary-layer-averaged, net chemical $\mathrm{NO}_{\mathrm{x}}$ loss partitioned by class of reaction as a function of $\mathrm{NO}_{\mathrm{x}}$. The losses to $\mathrm{HNO}_{3}$ for the BASE and RECYCLE cases are nearly identical and we show only the BASE case for clarity. The symbols on the $\mathrm{HNO}_{3}$ curve represent the mean $\mathrm{NO}_{\mathrm{x}}$ concentration of each bin. The $\mathrm{NO}_{\mathrm{x}}$ bins contain equal numbers of model points.

Changes in $\mathrm{OH}$ follow the same spatial pattern as $\mathrm{NO}_{\mathrm{x}}$ (Fig. 10a) and are about half as large - increases of $\sim 3-6 \%$ (mean of $5.2 \times 10^{4}$ molecules $\mathrm{cm}^{-3}$ and max of $2.3 \times 10^{5}$ molecules $\mathrm{cm}^{-3}$ ) in the RECYCLE case over the BASE case. Ozone also increases by up to $3 \%$ (Fig. 10b). In absolute values, ozone increases by a mean of $0.4 \mathrm{ppbv}$ and a maximum of 1 ppbv. The spatial pattern of the ozone change is shifted slightly downwind from the $\mathrm{NO}_{\mathrm{x}}$ and $\mathrm{OH}$ changes, reflecting the slower kinetics of ozone production compared to the timescale of the kinetics affecting $\mathrm{OH}$.

\subsection{Mid-tropospheric effects}

In addition to the boundary layer averages discussed above, we see changes between the RECYCLE and BASE at $600 \mathrm{mbar}$ are $\sim 4 \%$ for $\Sigma \mathrm{PNs}$ and $1-2 \%$ for $\mathrm{O}_{3}$ over the eastern part of the domain. $\mathrm{NO}_{\mathrm{x}}$ changes by $\sim 2.5-5 \%$ over most of the domain, with the hot spots occurring in the northwest and the east. By altering the mid-tropospheric burden, as well as the boundary layer burden of peroxy nitrates, monoterpene nitrates act to change the export of nitrogen from the continent, thus affecting ozone and $\mathrm{OH}$ concentrations downwind. These changes, while different in magnitude and location, should be qualitatively similar to the effects of isoprene nitrate chemistry, which have been discussed in detail in previous global modeling studies (e.g., von Kuhlmann et al., 2004; Fiore et al., 2005, 2011; Ito et al., 2007, 2009; Paulot et al., 2012). 


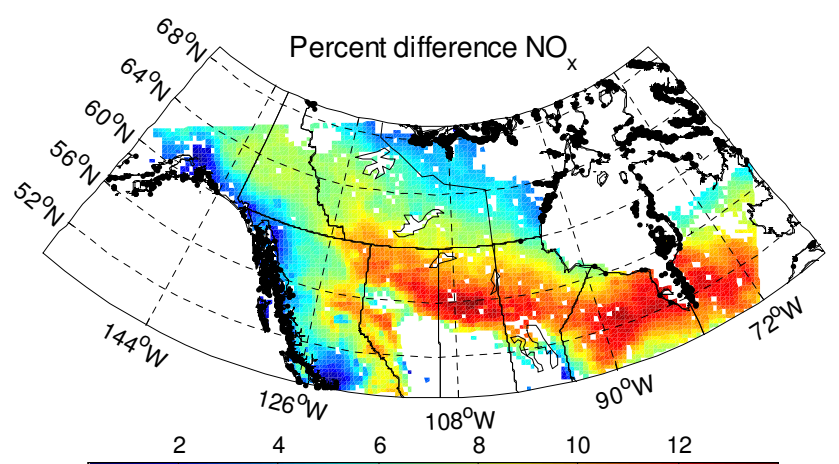

A
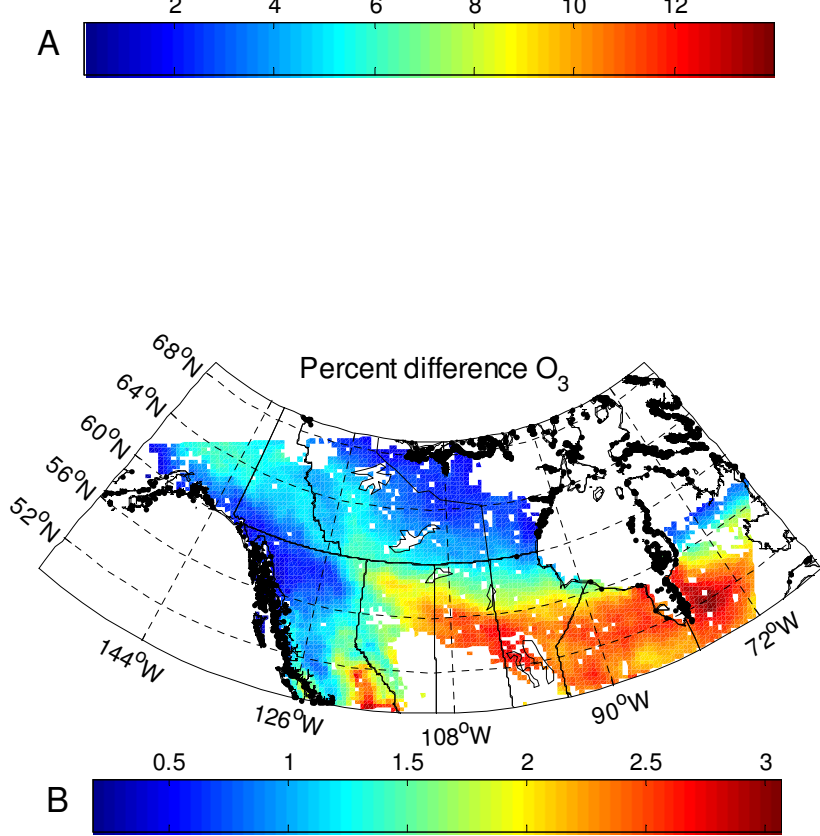

Fig. 10. Percent differences ((RECYCLE - BASE)/BASE $\times 100)$ between the RECYCLE and BASE cases for the $24 \mathrm{~h}$, boundarylayer-averaged (a) $\mathrm{NO}_{\mathrm{x}}$ and (b) $\mathrm{O}_{3}$ concentrations.

\section{Hydrolysis of tertiary MTNs}

Recent studies have shown that tertiary nitrates undergo rapid hydrolysis in aqueous solutions (Darer et al., 2011; Hu et al., 2011) and laboratory-generated SOA (Liu et al., 2012), with the assumed product being $\mathrm{HNO}_{3}$ and thus a "permanent" loss of nitrogen from the atmosphere. Browne et al. (2013) provide evidence in the ARCTAS data that particle-phase hydrolysis of MTNs is likely a significant loss process and an important source of $\mathrm{HNO}_{3}$. Due to the limitations of the model representation of organic aerosol (and its water content), the calculation of this chemistry is not attempted in WRF-Chem, but rather its effect is estimated using the organic aerosol loadings observed during ARCTAS. Two distinct regions of organic aerosol loading were encountered in the boundary layer during ARCTAS (excluding air masses with recent biomass burning or anthropogenic influences): a region with low loading (average of $1 \mu \mathrm{g} \mathrm{m}^{-3}$ ) and a high loading (average of $6.6 \mu \mathrm{g} \mathrm{m}^{-3}$ ). The area of high loading was correlated with higher concentrations of acetone, an oxidation product of some monoterpenes, consistent with previous observations of high SOA yields from monoterpene oxidation (e.g., Tunved et al., 2006; Fry et al., 2009; Hallquist et al., 2009; Slowik et al., 2010; Fry et al., 2011).

WRF-Chem predicts significantly less acetone $(24 \mathrm{~h}$ average boundary layer maximum of $\sim 500 \mathrm{pptv}$ ) than was measured during ARCTAS (boundary layer median $\sim 2$ ppbv) by proton transfer reaction mass spectrometry (Wisthaler et al., 2002), possibly indicating that monoterpene emissions and oxidation rates are underestimated or that the boundary conditions for acetone are too low. WRF-Chem does, however, predict areas of higher acetone concentration that are correlated with higher monoterpene concentrations. In these areas of high acetone ( $\geq 250 \mathrm{pptv}$ ) the organic aerosol loading is assumed to be $6.6 \mu \mathrm{g} \mathrm{m}^{-3}$. Elsewhere we assume $1 \mu \mathrm{g} \mathrm{m}^{-3}$ of aerosol. A hydrolysis loss rate is calculated only for the firstgeneration MTNs since presumably the formation of secondgeneration MTNs would be greatly diminished if hydrolysis of MTNs results in $\mathrm{HNO}_{3}$. The calculation includes the assumption that there is sufficient liquid water content in the aerosol and uses the same two hydrolysis rates as in Browne et al. (2013) to represent the possible range of hydrolysis rates. As discussed in Browne et al. (2013), there is substantial variation in the hydrolysis rates that have been reported in the literature. This range is likely due to variation of the rate depending upon the molecular structure of the nitrate, although comparing bulk solution experiments (Darer et al., 2011; Hu et al., 2011) to aerosol experiments (Liu et al., 2012) may also explain part of the variation. Additionally it is assumed that $75 \%$ of the MTNs formed from the reaction of $\mathrm{OH}$ with monoterpenes are tertiary, with a vapor pressure of $4 \times 10^{-6}$ torr, and that $\mathrm{NO}_{3}$ initiated oxidation results primarily in secondary organic nitrates whose lifetime to hydrolysis is long and can be ignored. With these assumptions and conditions, the calculated loss rate of MTNs and a corresponding production rate of $\mathrm{HNO}_{3}$ averaged over the entire domain of our calculations ranges from $0.11 \mathrm{pptvh}^{-1}$ (hydrolysis rate of $4.63 \times 10^{-5} \mathrm{~s}^{-1}$ ) to $1.01 \mathrm{pptv} \mathrm{h}^{-1}$ (hydrolysis rate of $4.15 \times 10^{-4} \mathrm{~s}^{-1}$ ). For comparison, the production rate of $\mathrm{HNO}_{3}$ via reaction of $\mathrm{NO}_{2}$ with $\mathrm{OH}$ in the domain is $3.14 \mathrm{pptv} \mathrm{h}^{-1}$, and thus this $\mathrm{HNO}_{3}$ source is $\sim 3.5$ to $32 \%$ as large as the known daytime $\mathrm{HNO}_{3}$ source.

This extra source of $\mathrm{HNO}_{3}$ initially seems incompatible with the $\mathrm{HNO}_{3}$ budget since WRF-Chem generally predicts larger concentrations of gas-phase $\mathrm{HNO}_{3}$ (Fig. $2 \mathrm{~g}$ ) than indicated by the ARCTAS measurements. This measurementmodel discrepancy of $\mathrm{HNO}_{3}$ is in part due to the higher $\mathrm{OH}$ concentrations predicted by WRF-Chem and the lower particle-phase $\mathrm{NO}_{3}^{-}$predicted by WRF-Chem compared to the observations. This extra loss would also necessitate an increase in the source of $\Sigma$ ANs. It is reasonable to believe that the source of $\Sigma$ ANs may be larger; in particular, monoterpenes may be increased (or sesquiterpene emissions added), 
while still maintaining agreement between the measurements and the model. Thus, this back-of-the-envelope calculation for this loss process is compatible with the measurementmodel comparison.

\section{Discussion}

The 3-D CTM calculations presented here indicate that oxidation of monoterpenes is a major sink of $\mathrm{NO}_{\mathrm{x}}$, a source of low-vapor-pressure MTNs, and a likely source of $\mathrm{HNO}_{3}$. Furthermore, given the differences in $\mathrm{O}_{3}$ and $\mathrm{OH}$ observed between the BASE and RECYCLE cases here, even larger differences are likely when comparing chemical mechanisms with MTN representation to those without.

The chemistry as parameterized here represents a range that brackets some of the key uncertainties of MTNs, while remaining consistent with the measurements from ARCTAS. Although there remain important issues to resolve concerning the gas-phase and multiphase chemistry of monoterpenes and MTNs, the results of these calculations indicate that this chemistry will be locally important wherever monoterpene emissions are a large fraction of VOC reactivity. In addition to these local changes in the chemistry of the atmosphere, the depositional loss of monoterpene nitrates will have important impacts on soil nitrogen and, consequently, the carbon cycle.

To our knowledge, there has been no prior work specifically looking at how the chemistry of MTNs impacts the composition and oxidizing capacity of the troposphere. Past global modeling studies, however, have included the oxidation of monoterpenes and the formation of MTNs (Horowitz et al., 2007; Ito et al., 2007, 2009), but have investigated the impact of MTNs in conjunction with isoprene-derived nitrates. Nevertheless, the results of these studies imply that modeled concentrations of $\mathrm{NO}_{\mathrm{x}}, \mathrm{OH}, \mathrm{O}_{3}$, and $\Sigma$ PNs are sensitive to the assumptions regarding the formation and fate of biogenic organic nitrates. Our finding that the production of MTNs from $\mathrm{NO}_{3}$ chemistry accounts for the majority of MTNs production at higher $\mathrm{NO}_{\mathrm{x}}$ concentrations is consistent with the results of Horowitz et al. (2007) for isoprene nitrates over the eastern United States and with the results of Pye et al. (2010), who found that the aerosol produced from monoterpenes and sesquiterpenes doubled over the southeastern United States when $\mathrm{NO}_{3}$ oxidation of these species was included in the model. Furthermore, a recent 1D model study simulating a northern Michigan forest calculated a nighttime production rate larger than the daytime production rate for the monoterpene-derived nitrates (Pratt et al., 2012). Together, these studies in conjunction with the work presented here indicate that the chemistry of MTNs is necessary to accurately simulate SOA and tropospheric chemistry.

Although the focus here was on the boreal forest of Canada, where there were observations to test the calculations, similar results are likely wherever monoterpene emissions are abundant, including the Mediterranean (e.g., Owen et al., 1997; Davison et al., 2009; Seco et al., 2011), the Pearl River delta (e.g., Wang et al., 2011), and ponderosa pine forests (e.g., Bouvier-Brown et al., 2009; Kim et al., 2010). It is worth noting that the speciation of the monoterpenes in these environments is likely different and that a parameterization using two representative monoterpenes may not be sufficient to capture the resulting differences in chemistry. We believe that limitations in our knowledge of monoterpene emissions and their gas-phase chemistry likely overshadow any uncertainties introduced with the use of two representative species in a chemical transport model. Nonetheless, our work has demonstrated that gas-phase monoterpene chemistry is important and further improvement in emissions and representations of their chemistry appropriate for reduced chemical mechanisms is warranted.

It is also likely that emissions of sesquiterpenes $\left(\mathrm{C}_{15} \mathrm{H}_{24}\right)$, whose emissions are currently lumped into the monoterpenes, are important sinks of $\mathrm{NO}_{\mathrm{x}}$ and sources of SOA. The oxidative chemistry of sesquiterpenes will likely have a different impact on the oxidative capacity of the atmosphere due to their higher reactivity and lower vapor pressures. For example, a recent study using 2-methyl-1-alkenes as surrogates for terpenes found $>22 \%$ yields of particle-phase $\beta$-hydroxy organic nitrates with a 15-carbon alkene (Matsunaga and Ziemann, 2010). This large yield suggests that sesquiterpenes (and their nitrates) should have significant local impacts on both $\mathrm{NO}_{\mathrm{y}}$ and SOA.

While the global impacts of this chemistry were not investigated here, Paulot et al. (2012), however, show that over the tropics the formation of isoprene nitrates results in a net chemical $\mathrm{NO}_{\mathrm{x}}$ sink, while over the oceans isoprene nitrates act as a net $\mathrm{NO}_{\mathrm{x}}$ source. It can be expected that MTNs have similar effects on global chemistry. MTNs will act to increase the ozone burden if the $\mathrm{NO}_{\mathrm{x}}$ is released in areas with a higher ozone production efficiency than that in which it was initially sequestered. This effect will depend on the details of the correct MTN chemistry, both directly through the reactions of MTNs and indirectly through their effect on $\mathrm{NO}_{\mathrm{y}}$ partitioning, $\mathrm{OH}$, and $\mathrm{O}_{3}$. For example, the concentration of $\Sigma \mathrm{PNs}$ is higher in the RECYCLE case than in the BASE case. As a result, the transport of $\mathrm{NO}_{\mathrm{x}}$ reservoirs from the continent to the oceans is larger in the RECYCLE than in the BASE case - a fact that amplifies differences in downwind $\mathrm{O}_{3}$.

\section{Conclusions}

Using the WRF-Chem model with an expanded organic nitrate representation, we are able to reproduce observations of a wide suite of chemicals, including $\Sigma$ ANs, observed during ARCTAS. Monoterpene nitrates were $\sim 5-12 \%$ of $\mathrm{NO}_{\mathrm{y}}$ over the boreal forest of Canada, and $\mathrm{NO}_{3}$ chemistry is the most important production pathway for MTNs when $\mathrm{NO}_{\mathrm{x}}$ is greater than $\sim 75 \mathrm{pptv}$. 
The fate of MTNs depends on the assumed oxidation products. In the BASE case, where oxidation results in a more functionalized nitrate that behaves like $\mathrm{HNO}_{3}$, deposition dominates the loss of MTNs. In this calculation MTN and $\mathrm{HNO}_{3}$ formation are approximately equal sinks of $\mathrm{NO}_{\mathrm{x}}$. In the RECYCLE case, where oxidation returns $\mathrm{NO}_{\mathrm{x}}$ to the atmosphere, MTNs are still $\sim 17 \%$ of the net $\mathrm{NO}_{\mathrm{x}}$ removal and this sink is similar to or greater than the net chemical sink from peroxy nitrates. These calculations are likely lower bounds on the net $\mathrm{NO}_{\mathrm{x}}$ sink represented by MTNs as particlephase hydrolysis of tertiary MTNs is likely an important loss process for MTNs, as is hinted at by the ARCTAS observations (Browne et al., 2013) and as suggested by laboratory measurements (Darer et al., 2011; Hu et al., 2011; Liu et al., 2012). The particle-phase hydrolysis could be between $\sim 7$ and $\sim 70 \%$ of the MTNs loss rate calculated using the WRF-Chem results as well as an additional source of $\mathrm{HNO}_{3}$ that ranges from a few percent to one-third as large as the source from the reaction of $\mathrm{NO}_{2}$ with $\mathrm{OH}$.

A complete representation of monoterpene chemistry will strain the capabilities of modern CTMs. However, until there is a more thorough understanding of monoterpene oxidation and the appropriate means of representing their chemistry in a condensed chemical mechanism, we recommend that models implement a basic gas-phase chemistry of monoterpenes in addition to their SOA chemistry. In parallel, evaluation of key parameters in the lab and consequences for ambient $\mathrm{O}_{3}$, $\mathrm{NO}_{\mathrm{x}}$ and $\mathrm{OH}$ should be explored both on local and global scales.

\section{Supplementary material related to this article is available online at http://www.atmos-chem-phys.net/14/ 1225/2014/acp-14-1225-2014-supplement.pdf.}

Acknowledgements. The analysis described here was supported by NASA grant NNX08AR13G and a NASA Earth Systems Science Fellowship to ECB. We thank E. Apel, D. R. Blake, and A. Wisthaler for use of their VOC measurements; W. H. Brune for use of the $\mathrm{OH}$ and $\mathrm{HO}_{2}$ measurements; J. L. Jimenez and M. J. Cubison for use of the organic aerosol measurements; P. O. Wennberg for use of the $\mathrm{HNO}_{3}$ measurement; and A. J. Weinheimer for use of the $\mathrm{NO}$ and $\mathrm{O}_{3}$ measurements. We thank W. H. Brune and I. Simpson for providing helpful feedback on the manuscript. We thank Wendy Goliff for providing the RACM2 chemistry. The model was run using on the Mako cluster under the Shared Research Computing Services (ShaRCS) pilot project funded by University of California, Office of the President.

Edited by: L. Ganzeveld

\section{References}

Ackermann, I. J., Hass, H., Memmesheimer, M., Ebel, A., Binkowski, F. S., and Shankar, U.: Modal aerosol dynamics model for Europe: Development and first applications, Atmos. Environ., 32, 2981-2999, 1998.

Apel, E. C., Hills, A. J., Lueb, R., Zindel, S., Eisele, S., and Riemer, D. D.: A fast-GC/MS system to measure $C_{2}$ to $C_{4}$ carbonyls and methanol aboard aircraft, J. Geophys. Res., 108, 8794, doi:10.1029/2002JD003199, 2003.

Arey, J., Aschmann, S. M., Kwok, E. S. C., and Atkinson, R.: Alkyl nitrate, hydroxyalkyl nitrate, and hydroxycarbonyl formation from the $\mathrm{NO}_{\mathrm{x}}$-air photooxidations of C5-C8 n-alkanes, J. Phys. Chem. A, 105, 1020-1027, doi:10.1021/jp003292z, 2001.

Atkinson, R., Baulch, D. L., Cox, R. A., Crowley, J. N., Hampson, R. F., Hynes, R. G., Jenkin, M. E., Rossi, M. J., Troe, J., and IUPAC Subcommittee: Evaluated kinetic and photochemical data for atmospheric chemistry: Volume II - gas phase reactions of organic species, Atmos. Chem. Phys., 6, 3625-4055, doi:10.5194/acp-6-3625-2006, 2006.

Bonn, B., von Kuhlmann, R. and Lawrence, M. G.: Influence of Biogenic Secondary Organic Aerosol Formation Approaches on Atmospheric Chemistry, J. Atmos. Chem., 51, 235-270, doi::10.1007/s10874-005-2778-x, 2005.

Bouvier-Brown, N. C., Goldstein, A. H., Gilman, J. B., Kuster, W. C., and de Gouw, J. A.: In-situ ambient quantification of monoterpenes, sesquiterpenes, and related oxygenated compounds during BEARPEX 2007: implications for gas- and particle-phase chemistry, Atmos. Chem. Phys., 9, 5505-5518, doi:10.5194/acp-9-5505-2009, 2009.

Browne, E. C. and Cohen, R. C.: Effects of biogenic nitrate chemistry on the $\mathrm{NO}_{\mathrm{x}}$ lifetime in remote continental regions, Atmos. Chem. Phys., 12, 11917-11932, doi:10.5194/acp-1211917-2012, 2012.

Browne, E. C., Min, K.-E., Wooldridge, P. J., Apel, E., Blake, D. R., Brune, W. H., Cantrell, C. A., Cubison, M. J., Diskin, G. S., Jimenez, J. L., Weinheimer, A. J., Wennberg, P. O., Wisthaler, A., and Cohen, R. C.: Observations of total $\mathrm{RONO}_{2}$ over the boreal forest: $\mathrm{NO}_{\mathrm{X}}$ sinks and $\mathrm{HNO}_{3}$ sources, Atmos. Chem. Phys., 13, 4543-4562, doi:10.5194/acp-13-4543-2013, 2013.

Carter, W. P. L. and Atkinson, R.: Alkyl nitrate formation from the atompsheric photoxidation of alkanes; a revised estimation method, J. Atmos. Chem., 8, 165-173, 1989.

Crounse, J. D., McKinney, K. A., Kwan, A. J., and Wennberg, P. O.: Measurement of gas-phase hydroperoxides by chemical ionization mass spectrometry, Anal. Chem., 78, 6726-6732, doi:10.1021/ac0604235, 2006.

Crounse, J. D., Paulot, F., Kjaergaard, H. G., and Wennberg, P. O.: Peroxy radical isomerization in the oxidation of isoprene, Phys. Chem. Chem. Phys., 13, 13607, doi:10.1039/c1cp21330j, 2011.

Crounse, J. D., Knap, H. C., Ørnsø, K. B., Jørgensen, S., Paulot, F., Kjaergaard, H. G., and Wennberg, P. O.: Atmospheric Fate of Methacrolein. 1. Peroxy Radical Isomerization Following Addition of $\mathrm{OH}$ and $\mathrm{O}_{2}$, J. Phys. Chem. A, 116, 5756-5762, doi:10.1021/jp211560u, 2012.

Darer, A. I., Cole-Filipiak, N. C., O'Connor, A. E., and Elrod, M. $\mathrm{J}$.: Formation and stability of atmospherically relevant isoprenederived organosulfates and organonitrates, Environ. Sci. Technol., 45, 1895-1902, doi:10.1021/es103797z, 2011. 
Davison, B., Taipale, R., Langford, B., Misztal, P., Fares, S., Matteucci, G., Loreto, F., Cape, J. N., Rinne, J., and Hewitt, C. N.: Concentrations and fluxes of biogenic volatile organic compounds above a Mediterranean macchia ecosystem in western Italy, Biogeosciences, 6, 1655-1670, doi:10.5194/bg-6-16552009, 2009.

Day, D. A., Wooldridge, P. J., Dillon, M. B., Thornton, J. A., and Cohen, R. C.: A thermal dissociation laser-induced fluorescence instrument for in situ detection of $\mathrm{NO}_{2}$, peroxy nitrates, alkyl nitrates, and $\mathrm{HNO}_{3}$, J. Geophys. Res., 107, 4046, doi:10.1029/2001JD000779, 2002.

Derwent, R. G., Collins, W. J., Jenkin, M. E., Johnson, C. E., and Stevenson, D. S.: The Global Distribution of Secondary Particulate Matter in a 3-D Lagrangian Chemistry Transport Model, J. Atmos. Chem., 44, 57-95, doi::10.1023/A:1022139814102, 2003.

Emmons, L. K., Walters, S., Hess, P. G., Lamarque, J.-F., Pfister, G. G., Fillmore, D., Granier, C., Guenther, A., Kinnison, D., Laepple, T., Orlando, J., Tie, X., Tyndall, G., Wiedinmyer, C., Baughcum, S. L., and Kloster, S.: Description and evaluation of the Model for Ozone and Related chemical Tracers, version 4 (MOZART-4), Geosci. Model Dev., 3, 43-67, doi:10.5194/gmd3-43-2010, 2010.

Faloona, I. C., Tan, D., Lesher, R. L., Hazen, N. L., Frame, C. L., Simpas, J. B., Harder, H., Martinez, M., Di Carlo, P., Ren, X., and Brune, W. H.: A laser-induced fluorescence instrument for detecting tropospheric $\mathrm{OH}$ and $\mathrm{HO}_{2}$ : Characteristics and calibration, J. Atmos. Chem., 47, 139-167, doi:10.1023/B:JOCH.0000021036.53185.0e, 2004.

Fiore, A. M., Horowitz, L. W., Purves, D. W., II, H. L., Evans, M. J., Wang, Y., Li, Q., and Yantosca, R. M.: Evaluating the contribution of changes in isoprene emissions to surface ozone trends over the eastern United States, J. Geophys. Res., 110, D12303, doi:10.1029/2004JD005485, 2005.

Fiore, A. M., Levy II, H., and Jaffe, D. A.: North American isoprene influence on intercontinental ozone pollution, Atmos. Chem. Phys., 11, 1697-1710, doi:10.5194/acp-11-1697-2011, 2011.

Freitas, S. R., Longo, K. M., Alonso, M. F., Pirre, M., Marecal, V., Grell, G., Stockler, R., Mello, R. F., and Sánchez Gácita, M.: PREP-CHEM-SRC - 1.0: a preprocessor of trace gas and aerosol emission fields for regional and global atmospheric chemistry models, Geosci. Model Dev., 4, 419-433, doi:10.5194/gmd-4419-2011, 2011.

Fry, J. L., Kiendler-Scharr, A., Rollins, A. W., Wooldridge, P. J., Brown, S. S., Fuchs, H., Dubé, W., Mensah, A., dal Maso, M., Tillmann, R., Dorn, H.-P., Brauers, T., and Cohen, R. C.: Organic nitrate and secondary organic aerosol yield from $\mathrm{NO}_{3}$ oxidation of $\beta$-pinene evaluated using a gas-phase kinetics/aerosol partitioning model, Atmos. Chem. Phys., 9, 14311449, doi:10.5194/acp-9-1431-2009, 2009.

Fry, J. L., Kiendler-Scharr, A., Rollins, A. W., Brauers, T., Brown, S. S., Dorn, H.-P., Dubé, W. P., Fuchs, H., Mensah, A., Rohrer, F., Tillmann, R., Wahner, A., Wooldridge, P. J., and Cohen, R. C.: SOA from limonene: role of $\mathrm{NO}_{3}$ in its generation and degradation, Atmos. Chem. Phys., 11, 3879-3894, doi:10.5194/acp-113879-2011, 2011.

Fulton, D., Gillespie, T., Fuentes, J., and Wang, D.: Volatile organic compound emissions from young black spruce trees, Agr. For- est Meteorol., 90, 247-255, doi:10.1016/S0168-1923(97)000804, 1998.

Goliff, W. S., Stockwell, W. R., and Lawson, C. V.: The regional atmospheric chemistry mechanism, version 2, Atmos. Environ. 68, 174-185, doi:10.1016/j.atmosenv.2012.11.038, 2013.

Grell, G. A., Peckham, S. E., Schmitz, R., McKeen, S. A., Frost, G., Skamarock, W. C., and Eder, B.: Fully coupled "online" chemistry within the WRF model, Atmos. Environ., 39, 6957-6975, doi:10.1016/j.atmosenv.2005.04.027, 2005.

Guenther, A., Karl, T., Harley, P., Wiedinmyer, C., Palmer, P. I., and Geron, C.: Estimates of global terrestrial isoprene emissions using MEGAN (Model of Emissions of Gases and Aerosols from Nature), Atmos. Chem. Phys., 6, 3181-3210, doi:10.5194/acp-63181-2006, 2006.

Hakola, H., Hellén, H., Hemmilä, M., Rinne, J., and Kulmala, M.: In situ measurements of volatile organic compounds in a boreal forest, Atmos. Chem. Phys., 12, 11665-11678, doi:10.5194/acp12-11665-2012, 2012.

Hallquist, M., Wenger, J. C., Baltensperger, U., Rudich, Y., Simpson, D., Claeys, M., Dommen, J., Donahue, N. M., George, C., Goldstein, A. H., Hamilton, J. F., Herrmann, H., Hoffmann, T., Iinuma, Y., Jang, M., Jenkin, M. E., Jimenez, J. L., Kiendler-Scharr, A., Maenhaut, W., McFiggans, G., Mentel, Th. F., Monod, A., Prévôt, A. S. H., Seinfeld, J. H., Surratt, J. D., Szmigielski, R., and Wildt, J.: The formation, properties and impact of secondary organic aerosol: current and emerging issues, Atmos. Chem. Phys., 9, 5155-5236, doi:10.5194/acp-9-51552009, 2009.

Hasson, A. S., Tyndall, G. S., and Orlando, J. J.: A product yield study of the reaction of $\mathrm{HO}_{2}$ radicals with ethyl peroxy $\left(\mathrm{C}_{2} \mathrm{H}_{5} \mathrm{O}_{2}\right)$, acetyl peroxy $\left(\mathrm{CH}_{3} \mathrm{C}(\mathrm{O}) \mathrm{O}_{2}\right)$, and acetonyl peroxy $\left(\mathrm{CH}_{3} \mathrm{C}(\mathrm{O}) \mathrm{CH}_{2} \mathrm{O}_{2}\right)$ radicals, J. Phys. Chem. A, 108, 5979-5989, doi:10.1021/jp048873t, 2004.

Horowitz, L. W., Fiore, A. M., Milly, G. P., Cohen, R. C., Perring, A., Wooldridge, P. J., Hess, P. G., Emmons, L. K., and Lamarque, J.-F.: Observational constraints on the chemistry of isoprene nitrates over the eastern United States, J. Geophys. Res., 112, D12S08, doi:10.1029/2006JD007747, 2007.

Hu, K. S., Darer, A. I., and Elrod, M. J.: Thermodynamics and kinetics of the hydrolysis of atmospherically relevant organonitrates and organosulfates, Atmos. Chem. Phys., 11, 8307-8320, doi:10.5194/acp-11-8307-2011, 2011.

Ito, A., Sillman, S., and Penner, J. E.: Effects of additional nonmethane volatile organic compounds, organic nitrates, and direct emissions of oxygenated organic species on global tropospheric chemistry, J. Geophys. Res., 112, D06309, doi:10.1029/2005JD006556, 2007.

Ito, A., Sillman, S., and Penner, J. E.: Global chemical transport model study of ozone response to changes in chemical kinetics and biogenic volatile organic compounds emissions due to increasing temperatures: Sensitivities to isoprene nitrate chemistry and grid resolution, J. Geophys. Res., 114, D09301, doi:10.1029/2008JD011254, 2009.

Jacob, D. J., Crawford, J. H., Maring, H., Clarke, A. D., Dibb, J. E., Emmons, L. K., Ferrare, R. A., Hostetler, C. A., Russell, P. B., Singh, H. B., Thompson, A. M., Shaw, G. E., McCauley, E., Pederson, J. R., and Fisher, J. A.: The Arctic Research of the Composition of the Troposphere from Aircraft and Satellites (ARCTAS) 
mission: design, execution, and first results, Atmos. Chem. Phys., 10, 5191-5212, doi:10.5194/acp-10-5191-2010, 2010.

Jenkin, M. E., Saunders, S. M., and Pilling, M. J.: The tropospheric degradation of volatile organic compounds: a protocol for mechanism development, Atmos. Environ., 31, 81-104, doi:10.1016/S1352-2310(96)00105-7, 1997.

Karl, T., Guenther, A., Yokelson, R. J., Greenberg, J., Potosnak, M., Blake, D. R., and Artaxo, P.: The tropical forest and fire emissions experiment: Emission, chemistry, and transport of biogenic volatile organic compounds in the lower atmosphere over Amazonia, J. Geophys. Res., 112, D18302, doi:10.1029/2007JD008539, 2007.

Kim, S., Karl, T., Guenther, A., Tyndall, G., Orlando, J., Harley, P., Rasmussen, R., and Apel, E.: Emissions and ambient distributions of Biogenic Volatile Organic Compounds (BVOC) in a ponderosa pine ecosystem: interpretation of PTR-MS mass spectra, Atmos. Chem. Phys., 10, 1759-1771, doi:10.5194/acp-101759-2010, 2010.

Leungsakul, S., Jeffries, H. E., and Kamens, R. M.: A kinetic mechanism for predicting secondary aerosol formation from the reactions of d-limonene in the presence of oxides of nitrogen and natural sunlight, Atmos. Environ., 39, 7063-7082, doi:10.1016/j.atmosenv.2005.08.024, 2005.

Liu, S., Shilling, J. E., Song, C., Hiranuma, N., Zaveri, R. A., and Russell, L. M.: Hydrolysis of organonitrate functional groups in aerosol particles, Aerosol Sci. Technol., 46, 1359-1369, 2012.

Liu, Y. J., Herdlinger-Blatt, I., McKinney, K. A., and Martin, S. T.: Production of methyl vinyl ketone and methacrolein via the hydroperoxyl pathway of isoprene oxidation, Atmos. Chem. Phys., 13, 5715-5730, doi:10.5194/acp-13-5715-2013, 2013.

Madronich, S. and Calvert, J. G.: Permutation reactions of organic peroxy radicals in the troposphere, J. Geophys. Res., 95, 56975715, doi:10.1029/JD095iD05p05697, 1990.

Matsunaga, A. and Ziemann, P. J.: Yields of $\beta$-hydroxynitrates, dihydroxynitrates, and trihydroxynitrates formed from $\mathrm{OH}$ radicalinitiated reactions of 2-methyl-1-alkenes, P. Natl. Acad. Sci., 107, 6664-6669, doi:10.1073/pnas.0910585107, 2010.

Middleton, P., Stockwell, W. R., and Carter, W. P. L.: Aggregation and analysis of volatile organic compound emissions for regional modeling, Atmos. Environ. A, 24, 1107-1133, doi:10.1016/0960-1686(90)90077-Z, 1990.

Owen, S., Boissard, C., Street, R. A., Duckham, S. C., Csiky, O., and Hewitt, C. N.: Screening of 18 Mediterranean plant species for volatile organic compound emissions, Atmos. Environ., 31, 101-117, doi:10.1016/S1352-2310(97)00078-2, 1997.

Paulot, F., Crounse, J. D., Kjaergaard, H. G., Kroll, J. H., Seinfeld, J. H., and Wennberg, P. O.: Isoprene photooxidation: new insights into the production of acids and organic nitrates, Atmos. Chem. Phys., 9, 1479-1501, doi:10.5194/acp-9-1479-2009, 2009a.

Paulot, F., Crounse, J. D., Kjaergaard, H. G., Kürten, A., Clair, S., M, J., Seinfeld, J. H., and Wennberg, P. O.: Unexpected Epoxide Formation in the Gas-Phase Photooxidation of Isoprene, Science, 325, 730-733, doi:10.1126/science.1172910, $2009 \mathrm{~b}$.

Paulot, F., Henze, D. K., and Wennberg, P. O.: Impact of the isoprene photochemical cascade on tropical ozone, Atmos. Chem. Phys., 12, 1307-1325, doi:10.5194/acp-12-1307-2012, 2012.

Peeters, J. and Müller, J.-F.: $\mathrm{HO}_{\mathrm{x}}$ radical regeneration in isoprene oxidation via peroxy radical isomerisations. II: experimental ev- idence and global impact, Phys. Chem. Chem. Phys., 12, 1422714235, doi:10.1039/c0cp00811g, 2010.

Perring, A. E., Bertram, T. H., Wooldridge, P. J., Fried, A., Heikes, B. G., Dibb, J., Crounse, J. D., Wennberg, P. O., Blake, N. J., Blake, D. R., Brune, W. H., Singh, H. B., and Cohen, R. C.: Airborne observations of total $\mathrm{RONO}_{2}$ : new constraints on the yield and lifetime of isoprene nitrates, Atmos. Chem. Phys., 9, 14511463, doi:10.5194/acp-9-1451-2009, 2009.

Pratt, K. A., Mielke, L. H., Shepson, P. B., Bryan, A. M., Steiner, A. L., Ortega, J., Daly, R., Helmig, D., Vogel, C. S., Griffith, S., Dusanter, S., Stevens, P. S., and Alaghmand, M.: Contributions of individual reactive biogenic volatile organic compounds to organic nitrates above a mixed forest, Atmos. Chem. Phys., 12, 10125-10143, doi:10.5194/acp-12-10125-2012, 2012.

Pye, H. O. T., Chan, A. W. H., Barkley, M. P., and Seinfeld, J. H.: Global modeling of organic aerosol: the importance of reactive nitrogen $\left(\mathrm{NO}_{\mathrm{x}}\right.$ and $\left.\mathrm{NO}_{3}\right)$, Atmos. Chem. Phys., 10, 1126111276, doi:10.5194/acp-10-11261-2010, 2010.

Räisänen, T., Ryyppö, A., and Kellomäki, S.: Monoterpene emission of a boreal Scots pine (Pinus sylvestris L.) forest, Agr. Forest Meteorol., 149, 808-819, doi:10.1016/j.agrformet.2008.11.001, 2009.

Rollins, A. W., Kiendler-Scharr, A., Fry, J. L., Brauers, T., Brown, S. S., Dorn, H.-P., Dubé, W. P., Fuchs, H., Mensah, A., Mentel, T. F., Rohrer, F., Tillmann, R., Wegener, R., Wooldridge, P. J., and Cohen, R. C.: Isoprene oxidation by nitrate radical: alkyl nitrate and secondary organic aerosol yields, Atmos. Chem. Phys., 9, 6685-6703, doi:10.5194/acp-9-6685-2009, 2009.

Rollins, A. W., Browne, E. C., Min, K.-E., Pusede, S. E., Wooldridge, P. J., Gentner, D. R., Goldstein, A. H., Liu, S., Day, D. A., Russell, L. M., and Cohen, R. C.: Evidence for $\mathrm{NO}_{\mathrm{x}}$ control over nighttime SOA formation, Science, 337, 1210-1212, doi:10.1126/science.1221520, 2012.

Saunders, S. M., Jenkin, M. E., Derwent, R. G., and Pilling, M. J.: Protocol for the development of the Master Chemical Mechanism, MCM v3 (Part A): tropospheric degradation of nonaromatic volatile organic compounds, Atmos. Chem. Phys., 3, 161-180, doi:10.5194/acp-3-161-2003, 2003.

Schell, B., Ackermann, I. J., Hass, H., Binkowski, F. S., and Ebel, A.: Modeling the formation of secondary organic aerosol within a comprehensive air quality model system, J. Geophys. Res., 106, 28275-28293, 2001.

Seco, R., Peñuelas, J., Filella, I., Llusià, J., Molowny-Horas, R., Schallhart, S., Metzger, A., Müller, M., and Hansel, A.: Contrasting winter and summer VOC mixing ratios at a forest site in the Western Mediterranean Basin: the effect of local biogenic emissions, Atmos. Chem. Phys., 11, 13161-13179, doi:10.5194/acp11-13161-2011, 2011.

Shepson, P. B., Mackay, E., and Muthuramu, K.: Henry's law constants and removal processes for several atmospheric $\beta$ hydroxy alkyl nitrates, Environ. Sci. Technol., 30, 3618-3623, doi:10.1021/es960538y, 1996.

Simpson, I. J., Akagi, S. K., Barletta, B., Blake, N. J., Choi, Y., Diskin, G. S., Fried, A., Fuelberg, H. E., Meinardi, S., Rowland, F. S., Vay, S. A., Weinheimer, A. J., Wennberg, P. O., Wiebring, P., Wisthaler, A., Yang, M., Yokelson, R. J., and Blake, D. R.: Boreal forest fire emissions in fresh Canadian smoke plumes: C1-C10 volatile organic compounds (VOCs), $\mathrm{CO}_{2}, \mathrm{CO}, \mathrm{NO}_{2}$, 
NO, $\mathrm{HCN}$ and $\mathrm{CH}_{3} \mathrm{CN}$, Atmos. Chem. Phys., 11, 6445-6463, doi:10.5194/acp-11-6445-2011, 2011.

Slowik, J. G., Stroud, C., Bottenheim, J. W., Brickell, P. C., Chang, R. Y.-W., Liggio, J., Makar, P. A., Martin, R. V., Moran, M. D., Shantz, N. C., Sjostedt, S. J., van Donkelaar, A., Vlasenko, A., Wiebe, H. A., Xia, A. G., Zhang, J., Leaitch, W. R., and Abbatt, J. P. D.: Characterization of a large biogenic secondary organic aerosol event from eastern Canadian forests, Atmos. Chem. Phys., 10, 2825-2845, doi:10.5194/acp-10-2825-2010, 2010.

Spirig, C., Guenther, A., Greenberg, J. P., Calanca, P., and Tarvainen, V.: Tethered balloon measurements of biogenic volatile organic compounds at a Boreal forest site, Atmos. Chem. Phys., 4, 215-229, doi:10.5194/acp-4-215-2004, 2004.

Spittler, M., Barnes, I., Bejan, I., Brockmann, K. J., Benter, T., and Wirtz, K.: Reactions of $\mathrm{NO}_{3}$ radicals with limonene and $\alpha$ pinene: Product and SOA formation, Atmos. Environ., 40, 116127, doi:10.1016/j.atmosenv.2005.09.093, 2006.

Thornton, J. A., Wooldridge, P. J., and Cohen, R. C.: Atmospheric $\mathrm{NO}_{2}$ : In situ Laser-Induced Fluorescence detection at parts per trillion mixing ratios, Anal. Chem., 72, 528-539, doi:10.1021/ac9908905, 2000.

Treves, K., Shragina, L., and Rudich, Y.: Henry's law constants of some $\beta-, \gamma-$, and $\delta$-hydroxy alkyl nitrates of atmospheric interest, Environ. Sci. Technol., 34, 1197-1203, doi:10.1021/es990558a, 2000.

Tunved, P., Hansson, H.-C., Kerminen, V.-M., Ström, J., Dal Maso, M., Lihavainen, H., Viisanen, Y., Aalto, P. P., Komppula, M., and Kulmala, M.: High natural aerosol loading over boreal forests, Science, 312, 261-263, doi:10.1126/science.1123052, 2006.

Tyndall, G. S., Cox, R. A., Granier, C., Lesclaux, R., Moortgat, G. K., Pilling, M. J., Ravishankara, A. R., and Wallington, T. J.: Atmospheric chemistry of small organic peroxy radicals, J. Geophys. Res., 106, 12157-12182, doi:10.1029/2000JD900746, 2001.

US EPA: Estimation programs interface Suite for Microsoft Windows v4.1, 2011.

von Kuhlmann, R., Lawrence, M. G., Pöschl, U., and Crutzen, P. J.: Sensitivities in global scale modeling of isoprene, Atmos. Chem. Phys., 4, 1-17, doi:10.5194/acp-4-1-2004, 2004.
Wang, X., Situ, S., Guenther, A., Chen, F., Wu, Z., Xia, B., and Wang, T.: Spatiotemporal variability of biogenic terpenoid emissions in Pearl River Delta, China, with high-resolution land-cover and meteorological data, Tellus B, 63, 241-254, doi:10.1111/j.1600-0889.2010.00523.x, 2011.

Weinheimer, A. J., Walega, J. G., Ridley, B. A., Gary, B. L., Blake, D. R., Blake, N. J., Rowland, F. S., Sachse, G. W., Anderson, B. E., and Collins, J. E.: Meridional distributions of $\mathrm{NO}_{\mathrm{x}}, \mathrm{NO}_{\mathrm{y}}$, and other species in the lower stratosphere and upper troposphere during AASE II, Geophys. Res. Lett., 21, 2583-2586, doi:10.1029/94GL01897, 1994.

Williams, B. J., Goldstein, A. H., Millet, D. B., Holzinger, R., Kreisberg, N. M., Hering, S. V., White, A. B., Worsnop, D. R., Allan, J. D., and Jimenez, J. L.: Chemical speciation of organic aerosol during the International Consortium for Atmospheric Research on Transport and Transformation 2004: Results from in situ measurements, J. Geophys. Res., 112, D10S26, doi:10.1029/2006JD007601, 2007.

Wisthaler, A., Hansel, A., Dickerson, R. R., and Crutzen, P. J.: Organic trace gas measurements by PTR-MS during INDOEX 1999, J. Geophys. Res., 107, 8024, doi:10.1029/2001JD000576, 2002.

Wooldridge, P. J., Perring, A. E., Bertram, T. H., Flocke, F. M., Roberts, J. M., Singh, H. B., Huey, L. G., Thornton, J. A., Wolfe, G. M., Murphy, J. G., Fry, J. L., Rollins, A. W., LaFranchi, B. W., and Cohen, R. C.: Total Peroxy Nitrates (SPNs) in the atmosphere: the Thermal Dissociation-Laser Induced Fluorescence (TD-LIF) technique and comparisons to speciated PAN measurements, Atmos. Meas. Tech., 3, 593-607, doi:10.5194/amt-3-5932010, 2010.

Xie, Y., Paulot, F., Carter, W. P. L., Nolte, C. G., Luecken, D. J., Hutzell, W. T., Wennberg, P. O., Cohen, R. C., and Pinder, R. W.: Understanding the impact of recent advances in isoprene photoxidation on simulations of regional air quality, Atmos. Chem. Phys., 13, 8439-8455, doi:10.5194/acp-13-8439-2013, 2013. 